\title{
A CASE OF EXTREME HYPERGLYCAEMIA DIABETIC COMA WITH RECOVERY
}

\author{
J. M. Beazley, M.B., Ch.B., D.Obst. R.C.O.G. \\ Senior House Officer, Withington Hospital, Manchester, 20
}

Blood sugar levels of the order of $1900 \mathrm{mg}$. per $100 \mathrm{ml}$. are seldom seen. A search of the literature has revealed four such cases.1, 3, 6, 7 One patient had a blood sugar level of $2,060 \mathrm{mg}$. per $100 \mathrm{ml}$. two hours after 20 units of insulin and did not recover. ${ }^{6}$ Another reached a level of $2,100 \mathrm{mg}$. per $100 \mathrm{ml}$. after 660 units of insulin, but $320 \mathrm{~g}$. of glucose had also been given. The two other patients had blood sugar levels of 2,000 mg. per $100 \mathrm{ml}^{1}{ }^{1}$ and $\mathrm{I}, 85^{\circ} \mathrm{mg}$. per $100 \mathrm{ml} .^{3}$ respectively. The former recovered after 100 units of insulin intramuscularly and 20 units intravenously. The latter recovered after 660 units. Unfortunately, only one case report mentions the route of administration of insulin. ${ }^{1}$

The present patient had a blood sugar of $I, 900$ mg. per $100 \mathrm{ml}$, , but recovered after the administration of 2,300 units of insulin intravenously. It is recorded in order to emphasize that extreme hyperglycaemia in diabetic ketosis is compatible with recovery, and also to draw attention to the vigorous treatment with insulin and intravenous fluids which may be required.

\section{Case Report}

An unemployed man, of only moderate intelligence, aged 39, was admitted to the Manchester Royal Infirmary under Dr. F. R. Ferguson on March I I, I958. He had suffered from diabetes for 22 years and during this period had been poorly controlled by diet and insulin. $\mathrm{He}$ had been admitted frequently either in hypoglycaemia or in ketosis. Since 1953 he had taken two doses of soluble insulin daily, 30 to 40 units each morning and 28 to 30 units each evening. His diet had varied between 2,000 and 2,500 calories daily.

On admission his mother stated that he had taken neither food nor insulin for four days and had become steadily more drowsy until the onset of coma three hours prior to admission. There had been no vomiting.

On examination he was deeply comatose and unresponsive to painful stimuli. The extremities were cyanosed and cold and the peripheral pulses were impalpable. The blood pressure in the arms was too low to be recorded with a sphygmomanometer. The respiratory rate was 30 per minute and the breath smelt of acctone. There was evidence of dehydration. The urine contained more than $2 \%$ of sugar and gave a strongly positive Rothera's test for acetone bodies. Gerhardt's test for acetoacetic acid was also positive. (Urine cultures set up at this time subsequently proved sterile.)

There was some muscle wasting in the legs and a left foot drop. The knee and ankle jerks were absent and the other tendon reflexes were sluggish Both plantar responses were flexor. (These neurological findings had been noted for seven years ag least.)

Attempts to record a temperature using af ordinary ward thermometer were unsuccessful: No other abnormality could be found and a diagnosis of diabetic coma with peripheral circulatory collapse was made.

Blood from a venepuncture in the arm was sent for analysis. Then 100 units of soluble insulin were given intravenously and an intravenous infusion of saline-lactate started. The blood sugar level was reported to be greater than $900 \mathrm{mg}$. per $100 \mathrm{ml}$., so a further 200 units of insulin were given intravenously. Two hours after admission a second blood sugar estimation showed an actual level of $1,600 \mathrm{mg}$. per $100 \mathrm{ml}$. The serum bicarbonate level at this time was $9.8 \mathrm{mEq} / \mathrm{l}$. and the potassium level was $4.6 \mathrm{mEq} / \mathrm{l}$.

On receipt of the second blood sugar result another 400 units of soluble insulin were administered intravenously. A third blood specimen, taken $3 \frac{1}{2}$ hours after admission, showed a blood sugar level of $\mathrm{I}, 900 \mathrm{mg}$. per $\mathrm{r} 00 \mathrm{ml}$. Accordingly, a further intravenous dose of 300 units of soluble insulin was given.

Other therapy during the first four hours consisted of the intravenous infusion of 2.5 litres of saline-lactate (each litre containing $130 \mathrm{mEq}$ of sodium, $100 \mathrm{mEq}$ of chloride and $30 \mathrm{mEq}$ of lactate) and two injections intravenously of 
mephine sulphate (1 $5 \mathrm{mg}$. each) in an attempt to raise the blood pressure. The latter appeared to have no effect. The patient remained unconscious and in peripheral failure for 18 hours. During the first 14 hours the body temperature still could not be recorded on an ordinary clinical thermometer. Eight hours after admission the blood sugar level had dropped to $1,080 \mathrm{mg}$. per $100 \mathrm{ml}$. and the scrum potassium to $3.6 \mathrm{mEq} / \mathrm{l}$. One litre of $5 \%$ dextrose, containing $40 \mathrm{mEq} / 1$. of potassium chloride, was given slowly over the next five hours; also intravenous insulin was given regularly at the rate of 100 units every two or three hours. Twenty-six hours after admission the patient had received a total of 2,300 units of soluble insulin and 71 . of fluid intravenously The blood sugar level was $170 \mathrm{mg}$. per $100 \mathrm{ml}$. and the patient was fully conscious with a pulse rate of 100 per minute and a blood pressure of $125 / 80$.

During the following 20 hours 41 . more of normal saline were given intravenously and a fluid diet of I,000 calories was given with a Ryle's tube. The insulin dosage was controlled by four-hourly urine testing, 25 units being given if the urine showed more than $2 \%$ of sugar. In the following three weeks the diet was increased to 2,500 calories and the soluble insulin adjusted to 36 units each morning and evening. The mid-morning blood sugar levels remained between 120 and $150 \mathrm{mg}$. per $100 \mathrm{ml}$.

\section{Discussion}

This case demonstrates not only recovery from extreme hyperglycaemia and coma, but also a temporary resistance to insulin in a patient normally responsive to small doses.

Reported cases with similar blood sugars 1, 3, 6, 7 received only one-third or less of the insulin given in the present case. Numerous instances of transient resistance are known, ${ }^{5}$ some of them receiving colossal doses of insulin, ${ }^{9}$ but such patients have had lower blood sugars, more severe ketosis and a source of infection. It is probable the temporary resistance in this patient was due only to ketosis, in which condition the efficacy of insulin is known to be reduced. ${ }^{4}$

It is interesting that 2,300 units were necessary even though the serum bicarbonate level droppeof to $9.8 \mathrm{mEq} / 1$. only.

Intravenous insulin is said to be moderatel more effective than subcutaneous insulin. ${ }^{5}$ Givers intravenously, it disappears from the body in mucl less than eight hours. Its site of destruction i⿱ unknown ${ }^{2}$ and it is not excreted in the urine in anything but negligible quantities. ${ }^{4}, 8$ It is sug: gested that such rapid removal from the body may account in part for the large doses of insuling necessary in this case.

The extensive use of intravenous insulin was. necessitated by prolonged circulatory collapse. W

\section{Summary}

A case of diabetic coma is reported in whicho the blood sugar level reached $1,900 \mathrm{mg}$. per $108^{\infty}$ $\mathrm{ml}$. Although normally controlled on 70 units of soluble insulin daily, the patient required $2,300 \overrightarrow{3}$ units and 71 . of intravenous fluid before fulb consciousness was regained, but when discharged he required only 60 units per day.

\section{Acknowledgments}

I should like to thank Dr. F. R. Ferguson permission to publish this case, and Dr. Pengelly for his helpful criticism.

\section{REFERENCES}

1. BRODRIBB, H. S. (195I), Brit. med. F., i, 172.

2. BRUCH, E. (1950), Arch. intern. Med., 86, 427.

3. DILLON, E. S., and DYER, W. W. (1935), Amer. F. med. Sci. 190,683 .

4. GOODMAN, L. S., and GILMAN, A. (ro55), 'The Pharmaco-3 logical Basis of 'Therapeutics', second edition, p. 1609, London,
Macmillan. Macmillan.

5. HAMPTON, A. G., HUNT, W. B., and MUL HOLLANDỌ

H. B. (1956), F. Amer. med. Ass., 161, 793.

6. LAWRENCE, R. D. (1934), Brit. med. F., i, 377.

7. MEYER, P. C., and SALT, H. B. (195I), Ibid., i, I 7 I.

8. MIRSKY, I. A., PODORE, C. J., WA CHMAN, J., and BROH: KAHN, R. H. (1948), Ұ. clin. Invest., 27, 515.

9. SHEPPARD, J. G. H. (1949), Brit. med. F., i, 576.

\section{NOTICE OF SPECIAL INTEREST TO SUBSCRIBERS:}

'WHY NOT HAVE YOUR COPIES OF THIS IOURNAL BOUND INTO YEARLY VOLUMES?'

\begin{abstract}
You can have your twelve monthly issues fully bound in dark green pin head cloth, lettered in gilt on spine with name of Journal, Volume Number and year, complete with index at front, for $22 \mathrm{~s}$. 6d. post free. A limited number of out of print journals are available to bind into volumes and make your library complete. Price on application giving details of issues required to complete back volumes.
\end{abstract}

THE
MEDICINE

9 G. JAMES STREET, LONDON, W.C.1
WHY NOT

HAVE YOUR

JOURNALS

BOUND? 